Vol 6, No 2, Oktober 2011: 82 - 98

\title{
PENINGKATAN HASIL BELAJAR SISWA DENGAN MENGGUNAKAN METODE KOOPERATIF DALAM MATA PELAJARAN DISAIN KECANTIKAN SISWA KELAS X SMKN 3 PEKANBARU
}

\author{
Helmiyati \\ Guru Tata Kecantikan SMKN 3 Pekanbaru
}

\begin{abstract}
ABSTRAK
Penelitian tindakan kelas ( classroom action research) ini terwujud untuk mengetahui peningkatan hasil belajar siswa melalui penerapan metode pembelajaran kooperatif dalam menggambar macam-macam bentuk wajah dan bagian-bagiannya serta model rambut yang sesuai. Setting penelitian ini adalah aktifitas siswa dalam pembelajaran yang dilakukan melalui diskusi kelompok, tugas gambar kelompok dan tugas gambar individu. Sumber informasi penelitian ini adalah guru, siswa dan kepala sekolah. Penelitian ini dilakukan dua siklus dengan 3 kali pertemuan, yang diawali dengan pra diskusi 2 kali pertemuan : Hasil penelitian menunjukkan bahwa adanya peningkatan aktifitas siswa dan hasil belajar siswa sebelum dan sesudah pembelajaran dilaksanakan yang mencakup aktivitas siswa dalam pembelajaran, keaktifan siswa dalam unjuk kerja, serta peningkatan hasil belajar siswa dan ketuntasan kompeten dibidang keahliannya. Selanjutnya diketahui bahwa dengan pembelajaran kooperatif memberikan kontribusi yang sangat positif terhadap peningkatan hasil belajar siswa dalam proses belajar mengajar, hal ini terlihat dari pengamatan kolaborator dan analisa data menunjukkan bahwa : hasil belajar siswa meningkat pada siklus I tingkat penguasaan baik hanya $75,67 \%$ dan terdapat tingkat penguasaan cukup $24,33 \%$, sedangkan pada siklus II 16,22 \% sangat baik dan tingkat penguasaan baik 83,78\%, ratarata aktifitas siswa dalam pembelajaran ( diskusi ) juga mengalami peningkatan pada siklus I rata-ratanya $71,71 \%$ sedangkan siklus II naik menjadi $94,23 \%$ pada keaktifan siswa ( sikap ) di siklus I 83,78 \% naik menjadi 92,48\%. Untuk keaktifan siswa dalam unjuk kerja mengalami kenaikan dari $86,18 \%$ menjadi $94,59 \%$.
\end{abstract}

Kata kunci : Pembelajaran kooperatif, aktifitas, hasil belajar.

\section{PENDAHULUAN}

Mata pelajaran Disain Kecantikan merupakan pembelajaran produktif untuk mempersiapkan kompetensi kejuruan program keahlian Tata Kecantikan Rambut kelas $\mathrm{X}$ pada SMKN 3 Pekanbaru dengan 2 jam pelajaran. Disain biasa diterjemahkan sebagai seni terapan, arsitektur, dan berbagai pencapaian kreatif lainnya. Dalam sebuah kalimat, kata "disain" bisa digunakan baik sebagai kata benda maupun kata kerja. Sebagai kata kerja, "disain" memiliki arti "proses untuk membuat dan menciptakan obyek baru". Sebagai kata benda, "disain" digunakan untuk menyebut hasil akhir dari sebuah proses kreatif, baik itu berwujud sebuah rencana, proposal, atau berbentuk obyek nyata. (dari wikipedia bahasa Indonesia, ensiklopedia bebas, 2011) . Desain Kecantikan adalah suatu konsep pemikiran untuk menciptakan gambar-gambar sebelum melakukan tata rias wajah dan rambut pada manusia (kurikulum 2004 Tata Kecantikan Rambut). Sebelum melakukan Tata Rias Wajah dan Rambut seorang penata rias harus membuat disain sesuai dengan bentuk wajah, kesempatan ,tujuan, kesempatan dan tujuan rias tersebut karena setiap orang memiliki 82 
bentuk wajah yang berbeda dan kegiatan yang berbeda pula. Penyampaian materi diberikan dengan metode ceramah, demonstrasi, latihan dan praktek menggambar.

SMK menurut undang - undang system Pendidikan Nasional No. 20 Tahun 2003 pasal 3 mengenai Tujuan Pendidikan Nasional dan penjelasan pasal 15 menyebutkan bahwa pendidikan kejuruan merupakan pendidikan menengah yang mempersiapkan peserta didik / siswa terutama bekerja dalam bidang tertentu, secara khusus tujuan program keahlian kecantikan rambut adalah membekali siswa dengan keterampilan (Skill), pengetahuan (Knowledge) dan sikap kerja (Attitude) dibidang kecantikan rambut. Pembelajaran di SMK merupakan sebuah upaya yang dilakukan untuk memperolah kompetensi atau berupa pengetahuan, keterampilan dan sikap yang diperlukan dalam suatu pekerjaan. Kompetensi merujuk kepada kemampuan seseorang untuk mentransfer pengetahuan dan keterampilan yang dimiliki pada lingkungan baru. Kompetensi lebih luas dari hanya keterampilan pada satu tugas atau pekerjaan tertentu, kompetensi termasuk serangkaian keterampilan, pengetahuan dan sikap-sikap yang sesuai (Sartono 2002). Kompetensi adalah sebagai sumber daya kemampuan perusahaan yang merupakan sumber keunggulan bersaing perusahaan terhadap pesaingnya. Kompetensi produktif yang dimiliki tamatan program keahlian tata kecantikan rambut menjadi pengamatan penulis adalah : Menguasai pembuatan gambar bentuk dengan sub kompetensi menggambar macam bentuk wajah dan bagian-bagaian wajah serta model rambut. Pembelajaran berbasis kompetensi merupakan wujud pelaksanaan kurikulum berbasis kompetensi sebagai curriculum in action. Salah satu rangkaian pembelajaran berbasis kompetensi pelaksanaannya adalah evaluasi pembelajaran berbasis kompetensi, melaksanakan pembelajaran selayaknya berpegang pada apa yang tertuang dalam perencanaan namun situasi yang dihadapi guru dalam melaksanakan pembelajaran mempunyai pengaruh besar terhadap proses pembelajaran itu sendiri oleh karena itu guru sepatutnya peka terhadap berbagai situasi yang dihadapi sehingga dapat menyesuaikan pola tingkah lakunya dalam mengajar dengan situasi yang dihadapi. Situasi pembelajaran itu banyak dipengaruhi oleh faktor-faktor sebagai berikut : 1) Faktor guru; 2) Faktor siswa; 3) Faktor kurikulum; 4) Faktor lingkungan (Sumanti, Asra, 2007)

Menurut Peraturan Pemerintah No. 19 tahun 2005 tentang Standar Nasional Pendidikan diantaranya : Kurikulum dilaksanakan dalam suasana hubungan siswa dan guru yang saling menerima dan menghargai, akrab, terbuka dan hangat dengan prinsip : Tut Wuri Handayani ing madio mangun karso ing ngarso sung tulodo (dibelakang memberikan daya dan kekuatan, ditengah membangun semangat dan prakarsa, didepan memberi contoh).

Siswa adalah sosok anak yang merupakan milik sang pencipta dan milik dirinya sendiri, keberhasilannya akan sangat tergantung dari pemanfaatan potensi yang dia miliki 
Vol 6, No 2, Oktober 2011: 82 - 98

keaktifan siswa dalam menjalani pembelajaran merupakan salah satu kunci keberhasilan pencapaian tujuan pendidikan. Siswa akan aktif dalam kegiatan belajarnya apabila ada motivasi, baik ekstrintik maupun instrinsik menurut Masnur Muslich (2007). Beberapa hal yang dapat merangsang tumbuhnya motivasi belajar aktif pada diri siswa antara lain sebagai berikut; 1) Penampilan guru yang hangat dan menumbuhkan partisipasi positif ; 2) Siswa mengetahui maksud dan tujuan pembelajaran; 3) Tersedia fasilitas, sumber belajar dan lingkungan yang mendukung; 4) Adanya prinsip pengetahuan penuh atas pribadi setiap siswa ; 5) Adanya konsistensi dalam penerapan aturan atau perlakuan oleh guru dalam pembelajaran ; 6) Adanya pemberian peningkatan dalam kegiatan belajar mengajar ( KBM ) ; 7) Jenis kegiatan pembelajaran menarik, menyenangkan dan menantang; 8) Penilaian hasil belajar dilakukan serius, objektif, teliti dan terbuka.

Penilaian merupakan suatu proses yang dilakukan melalui langkah-langkah perencanaan, penyusunan alat penilaian, pengumpulan informasi melalui sejumlah bukti yang menunjukkan pencapaian hasil belajar siswa, pengolahan, dan penggunaan informasi tentang hasil belajar siswa. Penilaian dilaksanakan melalui berbagai bentuk antara lain : penilaian unjuk kerja ( performance), penilaian sikap, penilaian tertulis ( paper and pencil test ), penilaian proyek, penilaian produk, penilaian melalui kumpulan hasil karja / karya siswa ( porifolio ), dan penilaian diri.

Penilaian hasil belajar baik formal maupun informal diadakan dalam suasana yang menyenangkan, sehingga memungkinkan siswa menunjukkan apa yang dipahami dan mampu dikerjakan. Berdasarkan pengamatan penulis dalam mata pelajaran disain kecantikan masih ada permasalahan: 1). Siswa kurang perhatian, inisiatif dan partisipasi; 2). Penyampaian materi bersifat monoton; 3) Metode mengajar kurang menarik; 4) Masih ada siswa yang kurang motivasi dalam belajar; 5) Ketuntasan belajar siswa belum sesuai dengan KKM 8,0 dikarenakan ada perubahan KKM dari 7,5 menjadi 8,0 yang telah diberlakukan oleh sekolah mulai semester 2 tahun 2010/2011. Kondisi ini terlihat hanya 10 orang siswa yang dapat nilai 8 dari 37 siswa dikelas pada awal pelajaran; 6) Hanya 50\% siswa yang menyelesaikan tugas / menggambar tepat waktu.

Untuk mengatasi hal tersebut diatas maka perlu dilakukan usaha mengatasi permasalahan tersebut dengan cara menerapkan metode pembelajaran kooperatif. Hal ini dipilih sebagai alternatif karena memiliki beberapa kelebihan. Sistim pembelajaran gotongroyong atau cooperative learning merupakan sistim pengajaran yang bekerja sama dengan sesama dalam tugas terstruktur. Salah satu cara terbaik untuk meningkatkan belajar aktif adalah dengan pemberian tugas belajar yang dilakukan dalam kelompok kecil siswa, dukungan sesama siswa dan keragaman pendapat pengetahuan, serta keterampilan mereka akan membantu menjadikan belajar bersama sebagai bagian bekerja dari iklim belajar di kelas. ( Melvin. L. Silberman,2007 ). Dengan metode pembelajaran kooperatif yang akan 84 
digunakan dalam penelitian tindakan kelas ini diharapkan partisipasi kontributif dan inisiatif siswa dalam bentuk keberanian menyampaikan pendapat, ide, gagasan, pertanyaan, kerja individu berupa gambar-gambar wajah, kerja kelompok serta tanggung jawab terhadap diri dalam kelompok meningkat, dengan kata lain kreatifitas dan keberanian siswa dalam pembelajaran jadi meningkat.

\section{Rumusan masalah pada pembelajaran Disain Kecantikan adalah :}

1. Apakan pembelajaran kooperatif dapat meningkatkan kemampuan siswa dalam disain kecantikan?

2. Apakan pembelajaran kooperatif dapat meningkatkan hasil belajar siswa ?

3. Apakah penggunaan metode pembelajaran kooperatif dapat meningkatkan keaktifan siswa, unjuk kerja serta motivasi belajar siswa?

Tujuan perbaikan pembelajaran ini adalah : setelah penelitian ini diakukan ada upaya pengembangan metode pembelajaran untuk meningkatkan hasil belajar siswa kelas $\mathrm{X}$ Tata Kecantikan Rambut SMKN 3 Pekanbaru. Berdasarkan uraian diatas penulis merumuskan hipotesis : Dengan penerapan metode pembelajaran kooperatif dapat meningkatkan motivasi dan hasil belajar siswa dalam mata pelajaran Disain Kecantikan pada kelas X Tata Kecantikan Rambut SMKN 3 Pekanbaru tahun pelajaran 2010/2011.

Menurut Slavin pembelajaran kooperatif adalah pembelajaran yang dilakukan secara kelompok , siswa dalam satu dijadikan kelompok - kelompok kecil yang terdiri dari 4 dan 5 orang untuk memahami konsep yang difasilitas oleh guru. Model pembelajaran kooperatif adalah model dengan setting kelompok-kelompok kecil dengan memperhatikan keberagaman anggota kelompok sebagai wadah siswa bekerjasama dan memecahkan suatu masalah melaui interaksi sosial dengan teman sebayanya, memberikan kesempatan pada siswa untuk mempelajari sesuatu dengan baik pada waktu yang bersamaan dan ia menjadi narasumber bagi teman yang lain. Jadi pembelajaran kooperatif merupakan model pembelajaran yang mengutamakan kerjasama diantara siswa untuk mencapai tujuan pembelajaran. Model pembelajaran kooperatif memiliki ciri-ciri : 1) Untuk menuntaskan meteri belajarnya, siswa belajar dalam kelompok secara kooperatif ; 2) Kelompok dibentuk dari siswa - siswa yang memiliki kemampuan tinggi, sedang dan rendah ; 3) Jika dalam kelas terdapat siswa-siswa yang terdiri dari beberapa ras, suku, budaya jenis kelamin yang berbeda, maka diupayakan agar dalam tiap kelompok terdiri dari ras, suku, budaya, jenis kelamin yang berbeda pula ; dan 4) Penghargaan lebih diutamakan pada kerja kelompok dari pada perorangan.

Pembelajaran kooperatif lebih dari sekedar belajar kelompok atau kerja kelompok karena dalam belajar kooperatif ada struktur dorongan atau tugas yang bersifat kooperatif 
Vol 6, No 2, Oktober 2011: 82 - 98

sehingga memungkinkan terjadi interaksi secara terbuka dan hubungan bersifat independen efektif diantara kelompok ( Sugandi,2002 : 14 ) Untuk mencapai hasil yang maksimal maka harus diterapkan lima unsur model pembelajaran kooperatif yaitu: 1) Saling ketergantungan positif; 2) Tanggung jawab perseorangan; 3) Tatap muka; 4) Komunikasi antar anggota; 5) Evaluasi proses kelompok.

Menurut Melvin. L. Silberman ( 2010 ): Salah satu cara terbaik untuk meningkatkan pembelajaran aktif adalah memberikan tugas-tugas belajar yang dikerjakan dalam tim-tim kecil, sering kali para siswa dapat lebih banyak belajar dengan cara ini di bandingkan jika guru mengajarkannya didepan kelas : dorongan dari teman-teman dan keragaman secara pandang pengetahuan dan keterampilan juga membantu pembelajaran berkelompok (kooperatif) sebagai bagian yang bermanfaat dalam pembelajaran yang aktif.

Pembelajaran kooperatif dapat menyediakan kesempatan kepada siswa untuk berpartisipasi aktif, sedangkan di pihak guru pembelajaran kooperatif ini kegiatan pokok adalah monitoring terhadap proses kelompok dan kemajuan belajar anggota kelompok dilakukan secara intensif. Disamping itu pembelajaran secara kelompok dapat meningkatkan kerja kelompok dan keterampilan sosial anak . Dibanding dengan pelajaran klasikal, pembelajaran dengan kelompok kecil misalnya memungkinkan dinamika siswa dikelas lebih leluasa, urusan pendapat dari individu siswa terhadap kelompok lebih produktif. Menurut Melvin . L. Silberman ( 2011, 12 ). Salah satu kompetensi guru adalah kompetensi pedagogik yaitu peserta merancang pembelajaran dan landasan kependidikan untuk kepentingan pembelajaran dimana seorang guru indikator esensialnya adalah menerapkan teori belajar dan pembelajaran berdasarkan karakteria siswa, kompetensi yang ingin di capai dan materi ajar , serta menyusun rancangan pembelajaran berdasarkan strategi yang dipilih (Dasim Budimansyah dkk,2008 ). Tugas utama guru harus berusaha membelajarkan siswa , membuat siswa mengalami belajar, pemilihan metoda dalam pembelajaran sangat perlu agar pembelajaran dikelas berjalan lancar dan menarik .

Agar belajar menjadi aktif siswa harus mengerjakan berbagai tugas, mereka harus menggunakan olah pikir, mengkaji gagasan, memecahkan masalah dan menerapkan apa yang dipelajari. Belajar aktif harus gesit, menyenangkan, bersemangat dan penuh gairah. Menurut Melvin .L. Silberman ( 2011,13 ) salah satu teknik dirancang untuk menjadikan siswa aktif sejak awal adalah: 1) Pembentukan team, membentuk siswa menjadi lebih mengenal satu sam lain atau menciptakan semangat kerjasama dan saling ketergantungan; 2) Penilaian serentak, mempelajari tentang sikap, pengetahuan dan pengalaman siswa; 3) Pelibatan belajar secara langsung, menciptakan minat awal terhadap pelajaran. Dan teknik ini mendorong siswa untuk mengambil peran aktif sejak awal.

Disekolah hasil belajar dinyatakan dalam angka-angka ( nilai ) dalam semua mata pelajaran yang diberikan. Jadi bentuk angka ( nilai ) ini merupakan prestasi ( hasil belajar 86 
siswa ). Adapun yang dimaksud dengan hasil belajar siswa adalah "Seperangkat nilai-nilai yang diperoleh siswa setelah melalui evaluasi yang didapat yaitu hasil belajar tingkat kognitif, efektif dan psikomotorik".

Sementara dalam mencapai nilai yang diperoleh tetap harus diperhatikan aktivitas siswa. Aktivitas siswa adalah segala kegiatan yang dilaksanakan baik secara jasmani dan rohani. Aktivitas siswa selama proses belajar mengajar merupakan salah satu indikator adanya keinginan siswa untuk belajar. Aktivitas siswa merupakan kegiatan atau prilaku yang terjadi selama proses mengajar. Kegiatan-kegiatan yang dimaksud adalah kegiatan yang mengarah pada proses belajar seperti bertanya, mengajukan pendapat, mengerjakan tugas,dapat menjawab pertanyaan guru dan bekerjasama dengan siswa lain,serta tanggung jawab terhadap tugas yang diberikan.

Aktifnya siswa selama proses belajar mengajar merupakan salah satu indikator adanya keinginan atau motivasi siswa untuk belajar. Siswa dikatakan memiliki aktifitas apabila ditemukan cirri-ciri prilaku seperti : sering bertanya kepada guru atau teman lain, mau mengerjakan tugas yang diberikan oleh guru. Mampu menjawab pertanyaan,senang diberi tugas belajar,dan lain sebagainnya.

\section{Penilaian Unjuk Kerja}

Penilain unjuk kerja merupakan penilaian yang dilakukan dengan mengamati kegiatan siswa dalam melakukan suatu tugas ( penilaian , hasil belajar SMK Gema Gawita, 2008 ). Penilaian ini cocok digunakan untuk menilai ketercapaian penguasaan kompetensi yang menuntut siswa melakukan tugas tertentu, seperti praktek dibengkel, praktek membuat gambar, praktek sholat, diskusi dan sebagainya. Cara penilaian ini dianggap lebih otentik dari pada tes tertulis, karena apa yang dimiliki lebih mencerminkan kemampuan siswa yang sebenarnya. Disini penulis mengambil penilaian unjuk kerja siswa dalam pembelajaran kelompok dimana dinilai aspek: mengingat, menggunakan alat yang tepat untuk pembuatan gambar individu maupun kelompok dan melakukan sesuai prosedur menggambar.

\section{Meningkatkan Hasil Belajar}

Ketuntasan hasil belajar siswa diukur melalui daya serap dan nilai yang diperoleh pada setiap kompetensi dan sub kompetensi. Apakah seorang siswa sudah dapat dikatakan kompeten atau belum, tergantung pada siswa mendapatkan ketuntasan minimum yang ditetapkan. Untuk kompetensi dan sub kompetensi Disain Kecantikan Rambut adalah apabila rata-rata nilai yang diperoleh diatas $80 \%$ yang ditunjukkan dengan hasil belajar siswa yang diperoleh.

Gambaran kegiatan pembelajaran kooperatif yang dilakukan dikelas X Tata Kecantikan Rambut adalah sebagai berikut ; 1) Pembagian kelompok yang terdiri dari 4 orang dan 5 
Vol 6, No 2, Oktober 2011: 82 - 98

orang dari 37 siswa yakni 8 kelompok; 2) Penjelasan materi secara singkat ; 3) Membagikan kertas kepada siswa berupa materi singkat dan menarik ; 4) Siswa melakukan diskusi tentang macam macam bentuk wajah ; 5) Masing masing kelompok menyampaikan hasil kelompok ; 6) Guru memperagakan kiat-kiat mengambar wajah ; 7) Setiap kelompok memilih satu macam bentuk wajah yang dipakai ; 8) Siswa mengumpulkan dan diberi penilaian kelompok ; 9) Mengumumkan nilai yang diperoleh kelompok masing masing ; 10) Mereview bersama antara guru dan siswa tentang materi ; 11) Tanya jawab dan memberikan tugas untuk pertemuan ketiga pada siklus I dan II.

Instrument yang digunakan adalah kurikulum, RPP, silabus, materi / bahan ajar, instrument dan lembar observasi. Tentang penilaian sikap, keaktifan siswa dalam unjuk kerja dan keberhasilan siswa/penguasaan siswa dalam menggambar.

\section{METODE PENELITIAN}

Penilaian tindakan kelas ini dilaksanakan di SMKN 3 Pekanbaru untuk mata pelajaran Disain Kecantikan, sebagai subjek dalam penelitian ini adalah siswa kelas $\mathrm{X}$ kecantikan rambut tahun pelajaran 2010 / 2011 dengan jumlah peserta didik 37 orang, semua perempuan. Penelitian ini dilaksanakan mulai bulan Februari sampai dengan April 2011 selama 3 bulan. Prosedur penelitian terdiri dari 2 siklus, tiap siklus dilakukan 3 kali pertemuan sesuai strategi pembelajaran dengan peningkatan hasil pembelajaran yang ingin dicapai. Setiap siklus terdiri dari : perencanaan tindakan, pelaksanaan, pengamatan tindakan serta refleksi. Pada pembelajaran pertama sampai ketiga merupakan pertemuan pra siklus untuk adaptasi bagi siswa, siklus I dimulai pada pertemuan ke empat.

Data dikumpulkan dengan teknik penugasan ( menggambar individu ), wawancara, observasi : Tentang sikap, aktifitas dan keaktifan siswa dalam pembelajaran. Teknik penugasan yaitu menggambar individu dilakukan pada pra siklus dua kali. Pada siklus I dan II masing-masing dua kali. Pada pertemuan ketiga diadakan pengisian angket lembar tentang sikap siswa pada mata pelajaran. Dapat dilihat pada tabel I.

Tabel 1 : Lembar Penilaian Sikap Siswa Terhadap Mata Pelajaran Dengan guru. 


\begin{tabular}{clcccc}
\hline & & \multicolumn{4}{c}{ Jawaban Siswa } \\
\cline { 3 - 6 } No & \multicolumn{1}{c}{ Pernyataan } & \multicolumn{3}{c}{ Ya } & \multicolumn{2}{c}{ Tidak } \\
\cline { 3 - 6 } & \multicolumn{2}{c}{$\begin{array}{c}\text { Jum } \\
\text { lah }\end{array}$} & $\%$ & $\begin{array}{c}\text { Jum } \\
\text { lah }\end{array}$ & $\%$ \\
\hline 1 & $\begin{array}{l}\text { Mata pelajaran disain kecantikan } \\
\text { sangat menarik }\end{array}$ & 17 & 45,94 & 20 & 54.05 \\
\hline 2 & $\begin{array}{l}\text { Pembelajaran kelompok } \\
\text { menyenangkan }\end{array}$ & 24 & 64,86 & 13 & 75,13 \\
\hline 3 & $\begin{array}{l}\text { Seluruh siswa wajib aktif dalam } \\
\text { kelompok }\end{array}$ & 24 & 64,86 & 13 & 35.13 \\
\hline 4 & $\begin{array}{l}\text { Agar hasil gambar baik harus } \\
\text { banyak latihan }\end{array}$ & 24 & 64,86 & 13 & 35,13 \\
\hline 5 & $\begin{array}{l}\text { Mata pelajaran disain kecantikan } \\
\text { mudah dipelajari }\end{array}$ & 18 & 48,64 & 19 & 51.35 \\
\hline 6 & $\begin{array}{l}\text { Guru harus memberikan motivasi } \\
\text { dalam belajar }\end{array}$ & 37 & 100,00 & - & - \\
\hline & $\quad$ & & & \\
\hline
\end{tabular}

Dari data yang dikumpulkan ternyata mata pelajaran disain kecantikan sangat menarik siswa tidak setuju ( $54,05 \%$ ) dan mata pelajaran disain kecantikan mudah siswa juga tidak setuju ( $51,35 \%$ ), sedangkan guru harus memberikan motivasi dalam belajar semua siswa setuju. Siswa umumnya senang dengan pembelajaran kelompok serta wajib aktif dalam kelompok siswa setuju ( 64,86 \% ). Dari sikap siswa terlihat bahwa mata pelajaran desain tidak menarik, sukar dipelajari, dan siswa merasa bosan dengan metode pembelajaran yang dilaksanakan selama ini dimana guru sebagai pusat perhatian, serta semua siswa setuju guru memberikan motivasi berarti guru harus selalu memotivasi siswa.

\section{HASIL DAN PEMBAHASAN}

\section{Siklus I}

\section{a. Perencanaan}

Perencanaan pada siklus I meliputi : mengkaji silabus dan merumuskan materi, membuat lembar penilaian, sikap unjuk kerja, keaktifan siswa, lembar penilaian produk ( gambar ) dan angket serta menetapkan jadwal penelitian

\section{b. Pelaksanaan}

Sebelum penelitian dilakukan pembelajaran tiga kali pertemuan ( pra siklus ) kemudian dilakukan pengamatan sikap siswa terhadap mata pelajaran dan guru. Selama kegiatan pembelajaran pada pra siklus, materi pelajaran diberikan secara ceramah dan demontrasi. Siswa diminta menggambar sesuai tugas yang diberikan. 
Tabel 2: Hasil Belajar Siswa pada Pra Siklus

\begin{tabular}{ccllcc}
\hline \multirow{2}{*}{ No } & \multirow{2}{*}{$\begin{array}{c}\text { Tingkat } \\
\text { Penguasaan }\end{array}$} & \multirow{2}{*}{ kriteria } & \multicolumn{2}{c}{ Siswa } \\
\cline { 4 - 6 } & & Sangat baik & Kompeten & 0 & Jumlah \\
\hline 1 & $9,0-10$ & Baik & kompeten & 10 & 27,03 \\
\hline 2 & $8,0-8,9$ & Cukup baik & kompeten & 27 & 72,97 \\
\hline 3 & $7,0-7,9$ & Kurang & Belum kompeten & 0 & - \\
\hline 4 & $6,0-6,9$ & Kurang sekali & Belum kompeten & 0 & - \\
\hline 5 & $5,0-5,9$ & \multicolumn{2}{c}{ Jumlah } & & $\mathbf{1 0 0 , 0 0}$ \\
\hline \multicolumn{7}{c}{} \\
\end{tabular}

Hasil penilaian pada pembelajaran pra siklus menunjukkan target ketuntasan belum tercapai, ini dibuktikan nilai cukup banyak ( $72,97 \%$ ), sedangkan siswa yang memperoleh nilai baik baru sebesar $27,03 \%$.

\section{c. Pengamatan}

Pengamatan yang dilakukan adalah partisipasi siswa dalam diskusi kelompok, keaktifan siswa dalam pembelajaran keaktifan siswa dalam unjuk kerja dengan penilaian produk gambar. Hasil analisa keaktifan siswa dalam diskusi kelompok dalam kelas dapat dilihat pada tabel 3

\section{Tabel 3 : Aktifitas Siswa Dalam Diskusi}

\begin{tabular}{|c|c|c|c|c|c|}
\hline \multirow[b]{2}{*}{ No } & \multirow[b]{2}{*}{ Aktifitas Yang Diamati } & \multicolumn{4}{|c|}{ Jumlah dan Persentase Aktifitas Siswa } \\
\hline & & $\begin{array}{l}\text { Perte } \\
\text { muan } 4\end{array}$ & $\begin{array}{l}\text { Perte } \\
\text { muan } 5\end{array}$ & $\begin{array}{c}\text { Perte } \\
\text { muan } 6\end{array}$ & $\begin{array}{l}\text { Rata- } \\
\text { Rata }\end{array}$ \\
\hline 1 & $\begin{array}{l}\text { Menjelaskan materi } \\
\text { dengan baik }\end{array}$ & $6(75)$ & $7(87,5)$ & $8(100)$ & 87,50 \\
\hline 2 & $\begin{array}{l}\text { Memperhatikan } \\
\text { penjelasan teman }\end{array}$ & $22(59,45)$ & $26(70,27)$ & $31(83,78)$ & 71,17 \\
\hline 3 & $\begin{array}{l}\text { Bertanya kepada teman } \\
\text { Bertanya kepada guru }\end{array}$ & $18(48,64)$ & $24(64,86)$ & $27(72,97)$ & 62,21 \\
\hline 4 & Mengerjakan tugas & $13(34)$ & $20(54,05)$ & $22(59,45)$ & 49,50 \\
\hline 5 & kelompok & $30(81,18)$ & $33(89,19)$ & $35(94,59)$ & 88,20 \\
\hline & $\begin{array}{l}\text { Jumlah siswa } \\
\text { yang hadir }\end{array}$ & 37 & 37 & 37 & \\
\hline
\end{tabular}

Persentasi siswa tentang bertanya pada guru pada masing-masing pertemuan sangat sedikit. Dan pertanyaan kepada teman juga sedikit, hal ini kemungkinan disebabkan belum terbiasa, tetapi pada setiap pertemuan mengalami peningkatan. 
Tabel 4 : Keaktifan Siswa Dalam Pembelajaran

\begin{tabular}{|c|c|c|c|c|c|c|c|c|}
\hline \multirow{3}{*}{ No } & \multirow{3}{*}{$\begin{array}{l}\text { Aspek Yang } \\
\text { Diamati }\end{array}$} & \multicolumn{7}{|c|}{ Jumlah dan Persentase Siswa } \\
\hline & & \multicolumn{2}{|c|}{ Pertemuan 4} & \multicolumn{2}{|c|}{ Pertemuan 5} & \multicolumn{2}{|c|}{ Pertemuan 6} & \multirow[b]{2}{*}{$\begin{array}{l}\text { Rata- } \\
\text { Rata }\end{array}$} \\
\hline & & $\begin{array}{l}\text { Jum } \\
\text { lah }\end{array}$ & $\%$ & $\begin{array}{l}\text { Jum } \\
\text { lah }\end{array}$ & $\%$ & $\begin{array}{l}\text { Jum } \\
\text { lah }\end{array}$ & $\%$ & \\
\hline 1 & Disiplin & 29 & 78,37 & 30 & 81,08 & 32 & 86,48 & 81,98 \\
\hline 2 & Tekun & 29 & 78,37 & 31 & 83,78 & 33 & 89,19 & 83,79 \\
\hline 3 & Tanggung jawab & 30 & 81,08 & 31 & 83,78 & 33 & 89,19 & 84,68 \\
\hline 4 & & 30 & 81,08 & 31 & 83,78 & 33 & 89,19 & 84,68 \\
\hline & Jumlah siswa 37 & & 79,72 & & 83,10 & & 88,51 & 83,77 \\
\hline
\end{tabular}

Tabel 5 : Keaktifan Siswa Dalam Unjuk Kerja

\begin{tabular}{|c|c|c|c|c|c|c|c|c|}
\hline \multirow{3}{*}{ No } & \multirow{3}{*}{$\begin{array}{l}\text { Aspek Yang } \\
\text { Diamati }\end{array}$} & \multicolumn{7}{|c|}{ Jumlah dan Persentase Siswa } \\
\hline & & \multicolumn{2}{|c|}{ Pertemuan 4} & \multicolumn{2}{|c|}{ Pertemuan 5} & \multicolumn{2}{|c|}{ Pertemuan 6} & \multirow[b]{2}{*}{$\begin{array}{c}\text { Rata } \\
\text { rata }\end{array}$} \\
\hline & & $\begin{array}{l}\text { Jum } \\
\text { lah }\end{array}$ & $\%$ & $\begin{array}{l}\text { Jum } \\
\text { lah }\end{array}$ & $\%$ & $\begin{array}{l}\text { Jum } \\
\text { lah }\end{array}$ & $\%$ & \\
\hline 1 & Mengingat & 32 & 86,46 & 31 & 83,78 & 33 & 89,19 & 86,48 \\
\hline 2 & Menggunakan & 31 & 83,78 & 32 & 84,46 & 33 & 89,19 & 86,48 \\
\hline 3 & $\begin{array}{l}\text { Nelakukan } \\
\text { sesuai prosedur }\end{array}$ & 31 & 83,78 & 32 & 84,46 & 32 & 89,19 & 85,48 \\
\hline & Jumlah siswa 37 & & 84,67 & & 82,32 & & 87,61 & 85,58 \\
\hline
\end{tabular}

Dari pengamatan keaktifan siswa dalam pembelajaran yang terdiri dari komponen disiplin, tekun, tanggung jawab dan kemandirian diperoleh data bahwa siswa menunjukkan keaktifan dalam pembelajaran rata rata $83,77 \%$. Belum semua siswa aktif dalam pembelajaran , sedangkan data keaktifan siswa dalam unjuk kerja yang terdiri dari komponen mengingat, menggunakan, dan melakukan sesuai prosedur diperoleh data siswa aktif unjuk kerja rata rata $85,58 \%$. Berarti masih ada siswa yang belum menggunakan alat / media tidak sesuai dengan prosedur.

Tabel 6 : Hasil Belajar Siswa pada Siklus I

\begin{tabular}{ccllcc}
\hline \multirow{2}{*}{ No } & \multirow{2}{*}{$\begin{array}{c}\text { Tingkat } \\
\text { Penguasaan }\end{array}$} & Kriteria & \multicolumn{2}{c}{ Siswa } \\
\cline { 4 - 6 } & $9,0-10$ & Sangat baik & Kompeten & 0 & $\%$ \\
\hline 1 & $8,0-8,9$ & Baik & Kompeten & 28 & 75,67 \\
2 & $7,0-7,9$ & Cukup baik & Kompeten & 9 & 24,33 \\
3 & $6,0-6,9$ & Kurang & Belum kompeten & 0 & 0 \\
4 & $5,0-5,9$ & Kurang sekali & Belum kompeten & 0 & 0 \\
5 & & & & & \\
\hline
\end{tabular}

Tingkat penguasaan bahan siswa ditentukan dari hasil gambar yang diperoleh. Berdasarkan analisis data hasil gambar pada siklus I diperoleh tingkat penguasaan siswa pada tabel 6, tingkat penguasaan siswa pada siklus I mencapai kriteria baik dan cukup 91 
Vol 6, No 2, Oktober 2011: 82 - 98

masing-masing sebesar 75,67 \% dan 24,33 \%. Dibandingkan dengan kegiatan prasiklus terjadi kenaikan penguasaan materi oleh siswa. Dari hasil analisa menunjukkan bahwa tidak ada siswa dibawah cukup. Dari segi lain ketuntasan belajar belum tercapai. Belum tuntasnya pembelajaran pada siklus I, maka perbaikan pembelajaran dilanjutkan pada siklus II.

\section{d. Refleksi}

Berdasarkan analisa data ditemukan hal hal sebagai berikut : 1) Keaktifan siswa dalam diskusi dalam menjelaskan materi, memperhatikan penjelasan, bertanya dan tugas kelompok meningkat dari pertemuan keempat sampai pertemuan keenam ; 2) Keaktifan siswa dalam pembelajaran tentang disiplin, tekun, tanggung jawab dan kemandirian ditinjau dari fase-fase pembelajaran mengalami peningkatan ; 3) Kemampuan unjuk kerja siswa dari pertemuan keempat sampai keenam meningkat ; 4) Hasil belajar yang dicapai siswa masuk dalam kategori baik.

\section{Sikkuls II}

\section{a. Perencanaan}

Perencanaan pada siklus II meliputi mengkaji silabus dan merencanakan materi, menyusun lembar kerja dan lembaran petunjuk, model-model rambut, kepada siswa lebih ditekankan untuk lebih aktif, memperlihatkan unjuk kerja dan produk lebih ditingkatkan sesuai prosedur.

\section{b. Pelaksanaan Tindakan}

Tindakan kedua pada siklus II dilaksanakan setelah pelaksanaan tugas pada silkus I, guru memberikan motivasi melalui kelompok dengan memberikan contoh serta perlakuan pembelajaran sama dengan siklus I. pelaksanaan tindakan pada siklus II ini memperbaiki kelemahan-kelemahan yang terdapat pada pelaksanaan tindakan I sesuai dengan hasil refleksi, berdasarkan kelemahan yang ditemukan pada siklus I, maka pada siklus II guru semaksimal mungkin membimbing dan memperhatikan siswa secara individu terutama siswa tidak mengerjakan tugas gambar.

\section{Pengamatan}

Pengamatan yang dilakukan adalah partisipasi siswa dalam keaktifan dalam diskusi keaktifan siswa dalam pembelajaran, keaktifan siswa dalam unjuk kerja dan hasil siswa dalam menggambar.

Hasil analisis pengamatan aktifitas semua siswa dalam diskusi dapat dilihat pada

tabel 7. Hasil pengamatan semua siswa aktif mengerjakan tugas, pemecahan masalah yang diberikan guru, semua siswa berdiskusi dengan temannya. Kegiatan pada siklus II memperlihatkan peningkatan aktifitas dalam kelas. Hal ini kemungkinan disebabkan karena guru memberikan contoh-contoh gambar yang menarik dan diperlihatkan model- model melalui media elektronik seperti LCD/infocus dan internet.

Tabel 7 : Aktifitas Siswa Dalam Diskusi

92 
Peningkatan Hasil Belajar Siswa Dengan Menggunakan Metode Kooperatif Dalam Mata Pelajaran Disain Kecantikan Siswa Kelas X SMKN 3 Pekanbaru

(Helmiyati)

\begin{tabular}{|c|c|c|c|c|c|c|c|c|}
\hline \multirow{3}{*}{ No } & \multirow{3}{*}{ Aspek Yang Diamati } & \multicolumn{7}{|c|}{ Jumlah dan Persentase Siswa } \\
\hline & & \multicolumn{2}{|c|}{ Pertemuan 7} & \multicolumn{2}{|c|}{ Pertemuan 8} & \multicolumn{2}{|c|}{ Pertemuan 9} & \multirow[b]{2}{*}{$\begin{array}{l}\text { Rata } \\
\text { rata }\end{array}$} \\
\hline & & $\begin{array}{l}\text { Jum } \\
\text { lah }\end{array}$ & $\%$ & $\begin{array}{l}\text { Jum } \\
\text { lah }\end{array}$ & $\%$ & $\begin{array}{l}\text { Jum } \\
\text { lah }\end{array}$ & $\%$ & \\
\hline 1 & $\begin{array}{l}\text { Menjelaskan materi } \\
\text { dengan baik }\end{array}$ & 8 & 100 & 8 & 100 & 8 & 100 & 100 \\
\hline 2 & $\begin{array}{l}\text { Memperhatikan } \\
\text { penjelasan teman }\end{array}$ & 32 & 86,48 & 34 & 91,89 & 37 & 100 & 92,79 \\
\hline 3 & $\begin{array}{l}\text { Bertanya kepada } \\
\text { teman }\end{array}$ & 37 & 100 & 37 & 100 & 37 & 100 & 100 \\
\hline 4 & $\begin{array}{l}\text { Bertanya kepada guru } \\
\text { Mengerjakan tugas }\end{array}$ & 26 & 70,67 & 29 & 78,83 & 32 & 86,48 & 78 \\
\hline 5 & kelompok & 37 & 100 & 37 & 100 & 37 & 100 & 100 \\
\hline & Jumlah siswa 37 & & 84,86 & & 89,19 & & 92,97 & 89,01 \\
\hline
\end{tabular}

Rata-rata tiga kali pertemuan $=89,01 \%$

Kemampuan menjelaskan materi dengan baik, sangat sempurna, kemampuan mengerjakan tugas kelompok dengan menggunakan contoh contoh gambar dan model dari media elektronik tentang gambar dan membuat gambar memperlihatkan hasil yang meningkat dibandingkan dengan kegiatan siklus I. Analisis kemampuan pemecahan masalah dilakukan berdasarkan jawaban yang benar dan aktifitas memberikan tanggapan pada diskusi. Tingkat keaktifan siswa dalam pembelajaran dapat dilihat pada tabel 8.

Tabel 8 : Keaktifan Siswa Dalam Pembelajaran ( sikap )

\begin{tabular}{|c|c|c|c|c|c|c|c|c|}
\hline \multirow{3}{*}{ No } & \multirow{3}{*}{$\begin{array}{l}\text { Aspek yang } \\
\text { Diamati }\end{array}$} & \multicolumn{7}{|c|}{ Jumlah dan Persentase Siswa } \\
\hline & & \multicolumn{2}{|c|}{ Pertemuan 7} & \multicolumn{2}{|c|}{ Pertemuan 8} & \multicolumn{2}{|c|}{ Pertemuan 9} & \multirow[b]{2}{*}{$\begin{array}{l}\text { Rata- } \\
\text { rata }\end{array}$} \\
\hline & & $\begin{array}{l}\text { Jum } \\
\text { lah }\end{array}$ & $\%$ & $\begin{array}{l}\text { Jum } \\
\text { lah }\end{array}$ & $\%$ & $\begin{array}{l}\text { Jum } \\
\text { lah }\end{array}$ & $\%$ & \\
\hline 1 & Disiplin & 33 & 89,19 & 35 & 94,59 & 36 & 97,29 & 93,37 \\
\hline 2 & Tekun & 33 & 89,19 & 34 & 91,89 & 35 & 94,59 & 91,89 \\
\hline 3 & Tanggung jawab & 34 & 91,89 & 35 & 94,59 & 36 & 97,29 & 94,50 \\
\hline 4 & kemandirian & 32 & 86,65 & 34 & 91,89 & 35 & 94,59 & 90,09 \\
\hline & Jumlah siswa 37 & & 89,19 & & 93,24 & & 95,94 & 92,46 \\
\hline
\end{tabular}

Rata-rata tiga kali pertemuan $=92,46 \%$

Tabel 9 : Data Keaktifan Siswa Dalam Unjuk Kerja 
Vol 6, No 2, Oktober 2011: 82 - 98

\begin{tabular}{llcccc}
\hline \multirow{2}{*}{ No } & \multirow{2}{*}{$\begin{array}{c}\text { Aktifitas Yang } \\
\text { Diamati }\end{array}$} & \multicolumn{4}{c}{ Jumlah dan Persentase Aktifitas Siswa } \\
\cline { 3 - 6 } & \multicolumn{1}{c}{ Pertemuan 7 } & Pertemuan 8 & Pertemuan 9 & $\begin{array}{c}\text { Rata- } \\
\text { rata }\end{array}$ \\
\hline 1 & Mengingat & $34(91,89)$ & $35(94,59)$ & $36(97,29)$ & 94,59 \\
2 & Menggunakan & $35(94,59)$ & $35(94,59)$ & $37(100)$ & 96,39 \\
3 & Melakukan sesuai & $34(91,89)$ & $34(91,89)$ & $35(94,59)$ & 92,79 \\
prosedur & & & & 97,29 & 94,59 \\
\hline & Jumlah siswa 37 & 92,79 & 93,69 & & \\
\hline
\end{tabular}

Rata-rata tiga kali pertemuan $=94,59 \%$

Dari pengamatan keaktifan siswa dalam komponen disiplin, tekun, tanggung jawab dan kemandirian dari tiga kali pertemuan terus meningkat dapat dilihat dari rata-rata tiga kali pertemuan itu siswa aktif yaitu 92,46\%. Sedangkan keaktifan siswa dalam unjuk kerja yang terdiri dari mengingat, menggunakan dan melakukan sesuai prosedur, maka pada aspek menggunakan pada pertemuan ke 9 mendapatkan $100 \%$ dan rata-rata tiga kali pertemuan untuk keaktifan unjuk kerja adalah 94,59\%. Berarti hanya ada 2 atau 3 orang yang tidak terlibat karena kurang sehat.

Selanjutnya pada tabel 10 dapat kita lihat bahwa 83,78 \% ( 31 siswa ) memperoleh nilai diatas 8,0 dan 6 orang siswa memperoleh nilai sangat baik yaitu diatas 9,0. Berarti hasil belajar siswa pada siklus II sangat meningkat dari pada siklus I, dan siswa memiliki kompetensi yang sangat baik.

Tabel 10: Hasil Belajar Siswa pada Siklus II

\begin{tabular}{ccllcc}
\hline \multirow{3}{*}{ No } & \multirow{2}{*}{$\begin{array}{c}\text { Tingkat } \\
\text { Penguasaan }\end{array}$} & & Kriteria & \multicolumn{2}{c}{ Siswa } \\
\cline { 3 - 5 } & & & Jumlah & $\%$ \\
\hline 1 & $9,0-10$ & Sangat baik & Kompoten & 6 & 16,22 \\
2 & $8,0-8,9$ & Baik & Kompoten & 31 & 83,78 \\
3 & $7,0-7,9$ & Cukup baik & Kompoten & 0 & 0 \\
4 & $6,0-6,9$ & Kurang & Belum kompoten & 0 & 0 \\
5 & $5,0-5,9$ & Kurang sekali & Belum kompoten & 0 & 0 \\
\hline \multicolumn{5}{r}{ Jumlah } \\
\end{tabular}

\section{c. Refleksi}

Berdasarkan analisis data ditemukan hal-hal sebagai berikut ; 1) Keaktifan siswa dalam diskusi kelompok tentang menjelaskan materi, memperhatikan penjelasan teman meningkat baik dari pertemuan ketujuh sampai pertemuan kesembilan pada siklus II terus meningkat, dalam menjelaskan semua kelompok aktif ; 2) Kemampuan unjuk kerja dalam mengingat dan menggunakan mengalami peningkatan ; 3) Hasil belajar yang dicapai siswa lebih baik jika dibandingkan dengan hasil siklus I. selanjutnya pada pertemuan ke sembilan diberikan lembaran penilaian sikap terhadap mata pelajaran dan guru sama dengan pra siklus. 
Tabel 11: Penilaian Sikap Siswa Terhadap Mata Pelajaran dan Guru

\begin{tabular}{|c|c|c|c|c|c|}
\hline \multirow{3}{*}{ No } & \multirow{3}{*}{ Pernyataan } & \multicolumn{4}{|c|}{ Jawaban Siswa } \\
\hline & & \multicolumn{2}{|c|}{$\mathrm{Ya}$} & \multicolumn{2}{|c|}{ Tidak } \\
\hline & & $\begin{array}{c}\text { Jum } \\
\text { lah }\end{array}$ & $\%$ & $\begin{array}{l}\text { Jum } \\
\text { lah }\end{array}$ & $\%$ \\
\hline 1 & $\begin{array}{l}\text { Mata pelajaran desain kecantikan sangat } \\
\text { menarik }\end{array}$ & 37 & 100 & & \\
\hline 2 & Pembelajaran kelompok menyenangkan & 37 & 100 & & \\
\hline 3 & $\begin{array}{l}\text { Seluruh siswa wajib aktif dalam kelompok } \\
\text { Agar hasil gambar baik harus banyak }\end{array}$ & 32 & 86 & & \\
\hline 4 & $\begin{array}{l}\text { latihan } \\
\text { Mata pelajaran desain kecantikan mudah }\end{array}$ & 37 & 100 & & \\
\hline 5 & $\begin{array}{l}\text { dipelajar } \\
\text { Guru harus memberikan motivasi dalam }\end{array}$ & 30 & 81,08 & & \\
\hline 6 & belajar & 37 & 100 & & \\
\hline
\end{tabular}

Dari data diatas terlihat bahwa : Mata pelajaran menyenangkan $100 \%$, pembelajaran kelompok menyenangkan $100 \%$, siswa harus berlatih $100 \%$ dan guru harus selalu memberikan dorongan agar siswa aktif dan termotivasi selalu dalam pembelajaran. Jadi terlihat sekali perbedaan dengan penilain sikap siswa sebelum dilakukan pada prasiklus dimana sikap siswa benar-benar aktif.

\section{d. Daya serap siswa}

Hasil akhir siklus II rata-rata nilai hasil belajar menunjukan diatas angka 8,0. Ini berarti dalam ketuntasan belajar tercapai setiap kompetensi dan sub kopetensi yang disajikan. Tercapainya ketuntasan belajar pada siklus II ini disebabkan oleh beberapa hal, anrata lain: 1) Siswa mulai memahami tentang kopetensi dan sub kopetensi dalam desain kecantikan setelah mengikuti pembelajaran kelompok ; 2) Pemberian contoh-contoh dan pengawasan dalam pembelajaran membantu siswa menambah pengetahuannya ; 3) Siswa lebih banyak mendapat informasi melalui diskusi dan tugas kelompok ; 4) Siswa merasa bergairah dan sangat aktif dalam pembelajaran karena guru telah memberikan kiat-kiat menggambar yang baik.

Tabel 12 : Hasil Belajar Siswa Pada Setiap Siklus

\begin{tabular}{ccccccc}
\hline & \multicolumn{7}{c}{ Tingkat Penguasaan \% } \\
\cline { 2 - 7 } Siklus & $\begin{array}{c}\text { Sangat } \\
\text { Baik }\end{array}$ & Baik & Cukup & Kurang & $\begin{array}{c}\text { Kurang } \\
\text { Sekali }\end{array}$ & $\begin{array}{c}\text { Rata- } \\
\text { rata }\end{array}$ \\
& $9-10$ & $8-8,9$ & $7-7,9$ & $6-6,9$ & $5-5,9$ & 0 \\
\hline Prasiklus & 0 & 27,03 & 72,97 & 0,0 & 0 & \\
Siklus I & 0 & 75,67 & 24,33 & 0,0 & 0 & \\
Siklus II & 16,22 & 83,78 & 0,0 & 0,0 & 0 & \\
& & & & & & \\
\hline
\end{tabular}


Vol 6, No 2, Oktober 2011: 82 - 98

Selanjutnya rata-rata aktifitas dalam diskusi melalui pembelajaran kooperatif dapat dilihat pada tabel 13 .

Tabel 13 : Rata-rata Aktifitas Siswa Melalui Pembelajaran Kooperatif

\begin{tabular}{clcc}
\hline \multirow{2}{*}{ No } & \multicolumn{1}{c}{ Aktifitas Yang Diamati } & Siklus I & Siklus II \\
& & Kriteria & Kriteria \\
\hline 1 & Menjelaskan materi dengan baik & 87,50 & 100,00 \\
2 & Memperhatikan penjelasan teman & 71,17 & 92,78 \\
3 & Bertanya kepada teman & 62,16 & 100,00 \\
4 & Bertanya kepada guru & 49,54 & 78,38 \\
5 & Mengerjakan tugas kelompok & 88,20 & 100,00 \\
\hline \multicolumn{2}{r}{ Rata-rata siklus I dan siklus II } & $71,71 \%$ & $94,23 \%$ \\
\hline
\end{tabular}

Dari hasil pengamatan pada siklus I dan II terlihat peningkatan yang baik pada penjelaskan materi siswa ke masing-masing kelompok serta dalam mengerjakan tugas kelompok pada siklus II benar-benar optimal. Dari data diatas pada aktifitas bertanya kepada guru hanya 78,38 \% ini disebabkan siswa malu-malu.

Tabel 14 : Rata-rata Keaktifan Siswa Dalam Pembelajaran ( sikap ) Siklus I dan II

\begin{tabular}{cccc}
\hline No & Aspek yang Diamati & \% Siklus I & $\%$ Siklus II \\
\hline 1 & Disiplin & 81,98 & 93,37 \\
2 & Tekun & 83,78 & 91,89 \\
3 & Tanggung jawab & 84,68 & 94,59 \\
4 & Kemandirian & 84,68 & 90,09 \\
\hline & Rata-rata siklus I dan siklus II & $83,78 \%$ & $92,48 \%$ \\
\hline
\end{tabular}

Tabel 15 : Rata-rata Keaktifan siswa dalam Unjuk Kerja pada Siklus I dan II

\begin{tabular}{cccc}
\hline \multirow{2}{*}{ No } & Aspek Yang Diamati & \multicolumn{2}{c}{ Jumlah dan Prestasi } \\
\cline { 3 - 4 } & & Unjuk Kerja Siswa \\
\hline 1 & Mengingat & 86,48 & \% Siklus II \\
2 & Menggunakan & 86,48 & 94,59 \\
3 & Melakukan sesuai prosedur & 85,58 & 96,39 \\
& Rata-rata siklus I dan siklus II & $86,25 \%$ & 92,79 \\
\hline
\end{tabular}

Tingkat keaktifan siswa dalam disiplin, tekun, tanggung jawab dan kemandirian meningkat pada siklus II, diatas $90 \%$ dan tingkat unjuk kerja juga diatas $90 \%$.

Tercapainya ketuntasan belajar ini memudahkan terjadinya peningkatan daya serap siswa dalam pembelajaran desain kecantikan. Hal ini disebabkan antara lain: 1) Tersusunnya rencana pembelajaran selama satu semester, sehingga siswa lebih terarah; 2) Pembelajaran 96 
dengan metoda kooperatif yang dilaksanakan dikelas membantu siswa dalam ketuntasan belajar ; 3) Tugas yang dikerjakan secara bersama dalam kelompok membantu peningkatan unjuk kerja siswa untuk membuat tugas individu ; 4) Penilaian yang dilakukan merinci kembali setelah pembelajaran menjadi motivasi bagi siswa untuk mempersiapkan dirinya dalam pembelajaran.

Hal lain yang mendukung daya serap siswa adalah : sarana / media pembelajaran yang ada dikelas, ruang kelas yang kondusif ( $A C)$, menggunakan media elektonik berupaLCD/ infocus serta adanya internet. Kondisi ini menjadikan suasana dan pengelolaan kelas akan lebih mudah, serta pendekatan kepada siswa dalam proses perbaikan pembelajaran sangat mendukung sekali.

\section{KESIMPULAN}

Kemampuan pemahaman masalah dengan metode pembelajaran kooperatif serta bantuan media berupa dokumen tentang macam macam bentuk wajah dan model model rambut memperlihatkan hasil yang meningkat dari sebelum nya (dari siklus I ke siklus II). Tercapainya hasil belajar pada siklus II ini disebakan oleh beberapa hal antara lain ; 1) Siswa mulai memahami macam-macam bentuk wajah dan bagiannya serta membuat model-model rambut yang sesuai dengan prosedur yang diberikan guru ; 2) Pembelajaran dengan metode kooperatif sangat membantu siswa memperdalam pengetahuannya; 3) Siswa lebih banyak mendapat informasi melalui diskusi dan tanya jawab dalam kelas; 4) Siswa dalam proses pembelajaran menjadi aktif karena berada dalam kelompok dan bergairah mengerjakan tugas karena mendapatkan motivasi dari guru; 5) Hasil belajar siswa meningkat karena nilai siswa disampaikan pada akhir pertemuan dan siswa bersemangat untuk meningkatkan nilainya.

\section{UCAPAN TERIMA KASIH}

Penulis mengucapkan terima kasih kepada bapak Prof Dr, Almasdi Syahza, SE, MP Guru Besar Universitas Riau yang telah menyediakan waktunya untuk membimbing. Semoga hasil penelitian tindakan kelas ini bermanfaat bagi peningkatan kompetensi siswa Tata Kecantikan SMKN 3 Pekanbaru.

\section{DAFTAR PUSTAKA}

Almasdi Syahza dan Indrawati., 2007. Peningkatan Hasil Belajar Mata Kuliah Manajemen Agribisnis Melalui Pemberian Hand-out Pada Mahasiswa Jurusan Manajemen, Fakultas Ekonomi, Universitas Riau, http://almasdi. unri.ac.id. Diakses tanggal 5 Februari 2010. 
Dasim Budimansyah, Suparlan dan Danny Meirawan., 2009. PAKEM ( Pembela jaran Aktif, Kreatif, Efektif dan Menyenangkan, Genesindo.

Departemen Pendidikan Nasional., 2004. Kurikulum Edisi 2004 Tata Kecantikan Rambut.

Joko Suharto., 2003. Penelitian Hasil Belajar, http://smkdki.net. Diakses tanggal 10 Februari 2011.

Masnur Muslich,,2007. KTSP ( Kurikulum Tingkat Satuan Pendidikan, Bumi Aksara.

Peraturan Pemerintah., 2005. Standar Nasional Pendidikan

Silberman. Melvin. L., 2011. Active Learning, Nusa Media.

Sartono., 2002. Konsep Penelitian Berbasis Kompetensi, PPPGK Kejuruan, Jakarta.

Slavin., 1997. Metoda Pembelajaran Koperatif, www.Sumberbacaan.com, Diakses tanggal 25 Januari 2010.

SMK Gema Gawita., 2008, Penilaian Hasil Belajar, www.smkgemagawitatgr. indosatscool.com/index.php/berita/2562. Diakses tanggal 25 Januari 2010.

Sumantri, Asra., 2009. Situasi Pembelajaran, www.Does-finder.com. Diakses tanggal 10 Februari 2011.

Wikipedia bahasa Indonesia, ensiklopedia bebas., 2011. www.wikipedia.org/wiki/Desain. Diakses tanggal 10 Februari 2011. 